Review

\title{
Estimation of Irrigation Water Pumping by Remote Sensing: Application of the SAMIR Model to Citrus under Mediterranean Climate Conditions
}

\author{
Idir Tazekrit $^{1}$ iD , Mohamed Benslimane ${ }^{1}$, Vincent Simonneaux ${ }^{2,3}$, Tarik Hartani ${ }^{4}$, \\ Abderrahmane Hamimed ${ }^{1}$ \\ ${ }^{1}$ Research on Biological Systems and Geomatics Laboratory, \\ University Mustapha Stambouli of Mascara, Algeria. \\ ${ }^{2}$ Mixed-Laboratories-International Remote Sensing and Water Resources in the Semi-Arid \\ Mediterranean of Marrakech, University Cadi Ayyad, Marrakech, Morocco. \\ ${ }^{3}$ Center for Space Studies of the Biosphère, University of Toulouse, CNRS, CNES, IRD, UPS, \\ Toulouse, France. \\ ${ }^{4}$ University Center of Tipaza, Tipaza, Algeria
}

Received in December 5, 2017 - Accepted in May 13, 2018

\begin{abstract}
Agricultural intensification has led to overexploitation of water resources, in particular of the underground resource. Estimating groundwater exploitation remains a serious problem in arid and semi-arid countries such as Algeria. The objective of this work is to estimate volumes of pumped irrigation water using the SAtellite Monitoring of Irrigation (SAMIR) model from satellite imagery. Eleven (11) Landsat-TM images covering an area of 20 hectares of citrus orchards with a drip irrigation system were used. Irrigation volumes simulated by SAMIR were compared with volumes of pumped irrigation water. The latter were recorded digitally by specific programmers over a one-year observation period. The results shows a slight discrepancy between total simulated and observed volumes, $138,782 \mathrm{~m}^{3}$ and 135,688.5 $\mathrm{m}^{3}$, respectively. The index of agreement $d$ and RMSE were 80.94 and 0.11 , respectively, while the ratio of observed to simulated volumes varied from 0.76 to 1.27 . $65 \%$ of the values compared differed by less than $10 \%$. A significant correlation was found between the two methods. This confirms the feasibility of estimating pumping by remote sensing without calculating theoretical crop water requirements.
\end{abstract}

Keywords: irrigation, remote sensing, water balance, water pumping, SAMIR, FAO-56.

\section{Estimativa do Bombeamento de Água para Irrigação Através de Deteção Remota: Aplicação do Modelo SAMIR à Cultura de Citrinos sob Condições Climáticas Mediterrâneas}

\begin{abstract}
Resumo
A intensificação da agricultura levou à sobreexploração de recursos hídricos, em particular os recursos subterrâneos. A dificuldade na sua estimativa continua a ser um problema sério em países como a Argélia. O objetivo deste trabalho é estimar o bombeamento de água agrícola através do modelo SAMIR (SAtellite Monitoring of IRrigation), com base no uso de imagens de satélite. Foram utilizadas onze (11) imagens Landsat-TM que abarcam uma área de 20 hectares de citrinos irrigados com sistema de gota a gota. As irrigações simuladas pelo SAMIR são confrontadas com as irrigações resultantes do bombeamento. Estes últimos foram gravados digitalmente por programadores específicos durante um período de observação de um ano. Os resultados mostram uma discrepância ligeira nos volumes totais simulados e observados, respectivamente de $138782 \mathrm{~m}^{3}$ e $135688,5 \mathrm{~m}^{3}$. O índice de concordância $d$ e $R M S E$ são respectivamente 80,94 e 0,11 , enquanto a relação entre observações e simulações varia de 0,76 a 1,27. $65 \%$ dos valores comparados têm diferenças inferiores a $10 \%$. Os métodos utilizados mostram uma correlação significativa. Isso confirma o nível de relevância da estimativa de bombeamento pelo método de sensoriamento remoto, sem calcular os requisitos teóricos de água das culturas.
\end{abstract}

Palavras-chave: irrigação, modelação, deteção remota, balanço hídrico, SAMIR, FAO-56.

Corresponding author: Idir Tazekrit, idir.tazekrit@hotmail.com. 


\section{Introduction}

In arid and semi-arid regions, the availability of water is the main limiting factor to plant productivity. Sustainable water management is a major problem, especially in irrigated areas. In such areas, tools that provide regional estimates of water balance components, particularly evapotranspiration, which is the main component of the water budget, will enable more sustainable management of water resources. Satellite remote sensing has great potential for monitoring agricultural water resources at different spatial and temporal scales. Remote sensing provides images acquired at regular intervals covering large geographical areas plus enables monitoring of vegetation dynamics through vegetation indexes (such as $N D V I$ ) and the detection of the water status through the land surface temperature, both of which are crucial factors controlling evapotranspiration. Methods based on remote sensing that make it possible to estimate the quantity of water in the soil at each instant have already been validated (Toureiro et al., 2016), making it possible to determine the water requirements of different crops (Allen et al., 1998). Water transpired from plants is closely linked with the normalized difference vegetation index (NDVI) (Choudhury et al., 1994; Bausch, 1995). The $N D V I$ allows the $K_{c b}$ coefficient (Basal crop coefficient) to be derived from satellite images and evapotranspiration to be calculated. The relationship between $N D V I$ and $K_{c b}$ has been the subject of many studies, (e.g. Michael and Bastiaanssen., 2000; Neale et al., 2005; Gonzalez-Dugo et al., 2009; Allen et al., 2011). Toureiro et al. (2016) showed a linear relationship between changes in the NDVI and vegetation coefficients over time. Calculating evapotranspiration enables crop water requirements to be estimated and hence the volume of water used by farmers. Groundwater, which is considered by farmers? as an individual resource (Margat, 2008), has resulted in several million drill holes around the world (Shah, 2009). In North Africa, groundwater is overexploited by more than 50\% (Kuper et al., 2016). Estimating pumped water remains problematic and involves considerable uncertainty (Margat, 2008). Many methods are available to estimate pumped volumes, often based on direct measurements (flowmeters) or theoretical crop requirements and statistics, or remote sensing combined with the theoretical needs of crops that can be adjusted by correction coefficients (Castaño et al., 2010; Wada et al., 2012). According to Blinda and Thivet (2006), agriculture accounts for up to $80 \%$ of total water demand in southern and eastern Mediterranean countries. In Algeria, groundwater is the resource the most threatened by agricultural development (Siebert et al., 2010). Algeria is one of the main regions in the world where groundwater is used for intensive agriculture, and the extraction of groundwater, which has been qualified as an informal revolution, often takes place outside public policy (Siebert et al., 2010).

In Algeria, the exploitation of renewable underground resources (ratio of withdrawal to recharge) is high.
In 2011, the average exploitation rate was calculated to be 80\% (Faysse et al., 2011), evidence for the overexploitation of most large aquifers, such as those in the plain of Mascara and the plateau of Mostaganem (Faysse et al., 2011). Castaño et al. (2010) claim there is no method of accurately quantifying such withdrawals that also satisfies the need for precision and low application cost over large areas. Evapotranspiration is considered to be the main flow in the hydric balance in these areas (Poussin et al., 2008). This parameter is usually estimated using remote sensing data, based on the estimation of surface energy using instantaneous thermal imaging at the moment of passage of the satellite (Delogu et al., 2012). These methods do not allow validation of the estimated soil surface temperatures and hence the extrapolation of evapotranspiration (Chirouze et al., 2014). Here, we use the soil vegetation atmosphere transfer (SVAT) to simulate evapotranspiration, using remote sensing data combined with monitoring of soil moisture. The FAO-56 dual crop coefficient method is the most widely used approach for estimating crop water requirements (Allen et al., 1998). It distinguishes between plant transpiration $\left(K_{c b}\right)$ and soil evaporation $\left(K_{e}\right)$. Soil evaporation $\left(K_{e}\right)$ is related to the fraction of vegetation cover $(F c)$ (Huete et al., 1985). The latter can be linearly linked to the $K_{c b}$ of plants (Choudhury et al., 1994).

The SAMIR model used in this study allows spatial simulation of evapotranspiration and crop water needs at the plot scale. Model inputs are evapotranspiration and local rainfall data, and a chronological series of $N D V I$, with medium resolution (Landsat 8). Combining remote sensing with the FAO-56 model provides actual information on the vegetative state $\left(K_{c b}\right.$ and $F c$ ) (Saadi et al., 2015). The main objective of present work was to develop a methodology based on the SAMIR approach to estimate hydrological variables, such as evapotranspiration and irrigation volumes from regional aquifers intended for agriculture under semi-arid climates. The reliability and precision of the model was evaluated by comparing simulated pumped and measured pumped volumes. However, other possible applications are estimation of citrus water requirements in semi-arid Mediterranean conditions, and the relationship test $\left(K_{c b}\right)$ as a function of the vegetation index $(N D V I)$ for citrus.

\section{Materials and Methods}

\subsection{Study area}

The Macta watershed is located in western Algeria (Fig. 1), between latitudes $34^{\circ} 28^{\prime} \mathrm{N}$ and longitudes $35^{\circ} 87^{\prime} \mathrm{N}$ and $0^{\circ} 52^{\prime} \mathrm{W}$ and $1^{\circ} 2^{\prime} \mathrm{E}$. It is drained by two main valleys, Wadi El Hammam, drains the northeastern slope of the Tellian Atlas, and Wadi Mebtouh the western slopes.

The climate in this area is semi-arid Mediterranean, characterized by a rainy season in the autumn and a hot dry season in the summer. The absolute minimum air tempera- 



Figure 1 - Satellite view and maps of the study area.

ture in winter is $6{ }^{\circ} \mathrm{C}$ to $8^{\circ} \mathrm{C}$. The absolute maximum temperature is $42{ }^{\circ} \mathrm{C}$. The average annual rainfall is $260 \mathrm{~mm}$ (Gliz et al., 2015). Water scarcity is a major problem for the vast agricultural plains in this area. The arid and semi-arid climatic conditions result in marked irregularity of the water resource in space and over time (Chibane et al., 2015). If the water needs of agricultural users are to be met in a sustainable way, there is an urgent need for rational management of irrigation water.

\subsection{Modeling by SAMIR}

Estimating the energy balance at the soil surface to provide continuous information on evapotranspiration and the monitoring of hydric balance of the plant is not sufficient (Bastiaanssen, 2000; Danelichen et al., 2014), modeling the interpolation of evapotranspiration using a model that integrates plant characteristics is indispensable. SVAT models such as BUDGET and GAPS can calculate the hydric balance of the crops, but inputting their data is complex compared to the that of the FAO CROPWAT model (Clarke et al., 1998).

A model to aid irrigation management based on the estimation of evapotranspiration by the FAO-56 method and satellite images was developed a part of the DEME-
TER project (Calera Belmonte et al., 2005). Other models that integrate soil water are available, but are more complex, because they are based on the division of soil into three superposed compartments (Zhang and Wegehenkel, 2006). Satellite images provide information on the actual development of vegetation through the NDVI. The latter is well correlated with the photosynthetic activity of plants and determines the water needs of crops and evapotranspiration (Simonneaux et al., 2009).

The satellite monitoring of irrigation (SAMIR) computer tool was developed as part of the SudMed project as a model of irrigation management based on satellite imagery and allows the spatial interpolation of evapotranspiration and the hydric balance of crops.

\subsubsection{Description of the model and theoretical background of the FAO-56 crop coefficient approach}

The SAMIR model uses the FAO-56 algorithm according to Simonneaux et al. (2009). The FAO-56 is based on the concepts of reference evapotranspiration ET0 and crop coefficients to separate the standard climatic demand (ET0) from the plant response ETc (Allen et al., 1998). The single method relies on the following equation:

$$
E T_{c}=E T 0 \times K_{c}
$$


where $K_{c}$ is the single crop coefficient. The daily reference evapotranspiration, ET0, is calculated using the FAO Penman-Monteith method (Allen et al., 1998).

Daily values of the climatic parameters used for calculating ET0 are obtained from the weather station located closest to the experimental station.

The dual method accounts for variations in soil water availability, inducing either stress or soil evaporation, and is based on the following equation:

$$
E T_{c}=E T 0 \times\left(K_{c b} \times K_{s}+K_{e}\right)
$$

where $K_{c b}$ is the basal crop coefficient derived from NDVI using a combination of relationships (4) and (5), (Allen et al., 1998; González-Piqueras, 2006). $K_{c b}$ is adjusted by the water stress coefficient $K_{s} . K_{e}$ is the coefficient of evaporation of the fraction of bare ground; $K_{s}$ is the coefficient of hydric stress, calculated from the hydric state of the soil compartment and the maximum plant evaporation. $K_{e}$ and $K_{s}$ are calculated based on the computed daily water balance in the surface soil evaporation layer of effective depth $\left(Z_{e}\right)$ and in the root zone $\left(Z_{r}\right)$, respectively, according to Allen et al. (1998).

We consider that $\mathrm{K}_{\mathrm{s}}=0$ when the three compartments of the soil are filled and $\mathrm{K}_{\mathrm{s}}=1$ when they are empty. The drying of the three compartments is assumed to be linear, allowing the Zhang and Wegehenkel (2006) ground model to adjust $K_{e}$ according to $K_{s}$.

The soil hydric balance is performed by combining the FAO-56 approach with the empirical model of Zhang and Wegehenkel (2006) dividing the soil into three compartments.

These coefficients are determined from NDVI, derived from satellite imagery after their daily interpolation either linearly or by spline.

This method is well suited to the spatialization of $E T$ over large areas, including olive and citrus orchards, using Landsat TM and MODIS images (Simonneaux et al., 2009; Benhadj et al., 2012).

SAMIR can use the FAO LocClim software by calculating reference evapotranspiration from the daily interpolation of climate variables. It also uses climate models such as ALADIN (Simonneaux et al., 2009). At the parcel scale, real measurements from the closest weather stations can be used as inputs; in particular, daily rainfall values can be spatially interpolated.

The values that can be considered constant in space and over time and should be defined by the user are: minimum and maximum root depth, soil depth, the easily evaporative fraction of the soil, water contents at field capacity and wilting point, and the initial water reserves of the soil.

SAMIR uses soil maps, in which we define three horizons of different water content (Zhang and Wegehenkel, 2006). The thickness of the first horizon is fixed, it controls evaporation from the soil, while the second horizon thickness is variable and controls transpiration from the vegeta- tion; it is controlled by the NDVI and the plant cover. The deep horizon allows drainage below a depth of two (2) meters.

The use of high-resolution images acquired at intervals of 15 days or more to learn about the phenological state of crops is a recognized method (Minacapilli et al., 2008; Ray and Dadhwal., 2001). The NDVI index resulting from the processing of satellite images is linearly related to $K_{c b}$. Depending on the type of crop, different relationships are available in the literature (Ray and Dadhwal., 2001; Duchemin et al., 2006).

The start of irrigation is systematically triggered by given level of depletion of the usable groundwater reserve. This threshold is determined by the user and takes the irrigator's practices into consideration. This kind of irrigation management is useful at the parcel scale, as it makes it possible to define the frequency of inputs and of irrigation. At larger scales, SAMIR provides comprehensive information on water consumption at the end of the crop cycle, not in the chronological order of irrigation.

\subsubsection{Water balance and simulation of irrigation}

The equation SAMIR uses to calculate the hydric balance for each pixel of the land occupation map is:

$$
\begin{aligned}
& I+R(\text { contributions })-D_{p} \\
& +E T(\text { exits })=D W(\text { stock variation })
\end{aligned}
$$

where $I, R$ represent irrigation and rainfall, respectively. $D_{p}$ represents deep drainage at a depth of more than two (2) meters and $E T$ real evaporation. $D W$ is the change in water content of the soil. Thus, the SAMIR model simulates irrigation based on the change in the water stored in each pixel of the land occupation, taking into consideration the basic data defined by the user:

- Initial water content before irrigation starts;

- The wet fraction of the soil, depending on the system used. In our case, it is $12 \%$, the root depth is about $1 \mathrm{~m}$;

- A drying rate that allows the launching of irrigation;

- The irrigation recharge rate and the $K_{c b}$ value, which informs about the end of the vegetative cycle and of all irrigation.

\subsubsection{Application of the SAMIR model to the study area}

The experimental study of the Macta coastal plain was based on the use of eleven (11) Landsat TM images acquired over an observation period of one year, from May 2015 to May 2016, and covering a citrus parcel of 20 hectares.

This parcel was chosen because it enabled good control of the irrigation system, providing information about pumped water volumes, sensors for the measurement of soil moisture, and automatic recording of data of the water pumped from the wells (Fig. 2). The simulation results were validated by comparing them with the volume of water used by the irrigator. We hypothesized that the recorded 


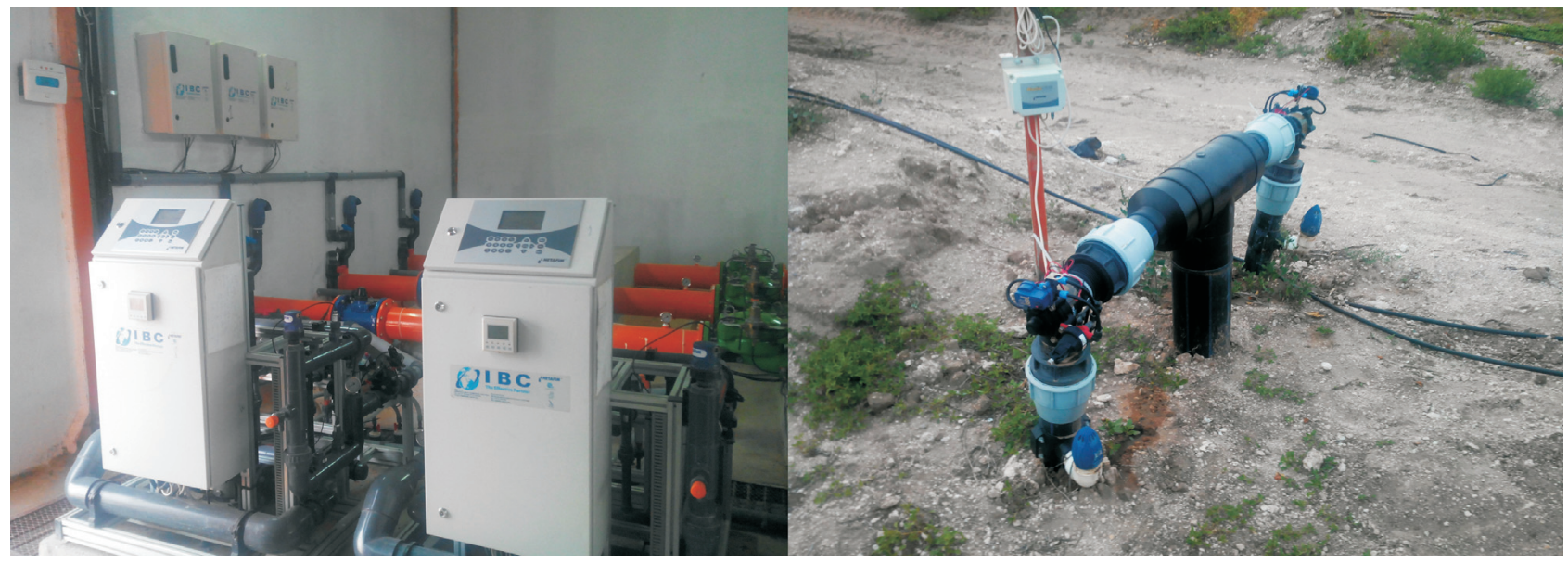

Figure 2 - Irrigation control equipment, programmer and solenoid valve.

volume data are accurate because they are provided by control programmers, management, and the record of volumes kept by the NETAFIM brand.

Comparison of real pumped volumes provided by the irrigator and pumped volumes simulated by SAMIR showed that model estimates of pumped groundwater are very reliable; this information is often difficult to quantify (Faysse et al., 2011).

The images were used to calculate the NDVI vegetation index, knowing that land occupation includes only citrus orchards, with $N D V I$ values ranging from 0.24 to 0.38 . $F c$ measured in situ is about $10 \%$ of the soil surface, the relationship between $F c$ and $N D V I$ is considered linear (Simonneaux et al., 2008; Bezerra et al., 2010; GonzálezPiqueras, 2006). According to González-Piqueras (2006), if less than $80 \%$, the plant cover factor can be calculated using the following formula:

$$
F c=1.19 \times(N D V I-N D V I S)
$$

where $N D V I$ s corresponds to the $N D V I$ of a bare soil, estimated at 0.14 (González-Piqueras, 2006). The variation in $K_{c b}$ as a function of $F c$ is determined by the relation of the following FAO method (Allen et al., 1998):

$$
K c b=(0.3026 \cdot F c)+0.4421
$$

The evapotranspiration and rainfall data used are those from the closest meteorological station to the study site, managed by the National Meteorological Office (ONM), located north of the Macta (Figs. 3 and 4).

Both Figs. 4 and 5 show a water deficit throughout the study period, which in the SAMIR model leads to successive irrigation events to compensate for the deficit. Validation was performed at the end of the cycle, by comparing the estimated irrigation simulated by the model and total measured irrigation volumes.

\subsection{Determination of model performance}

The parameters used as the model database were adjusted to validate and calibrate the model by obtaining simulated solutions, optimally close to the observed data (Abrishamchi et al., 2007). The performance criteria are expressed by the ratio of the simulated and the observed flows, and are estimated statistically by calculating the performance indices (Koffi, 2007).

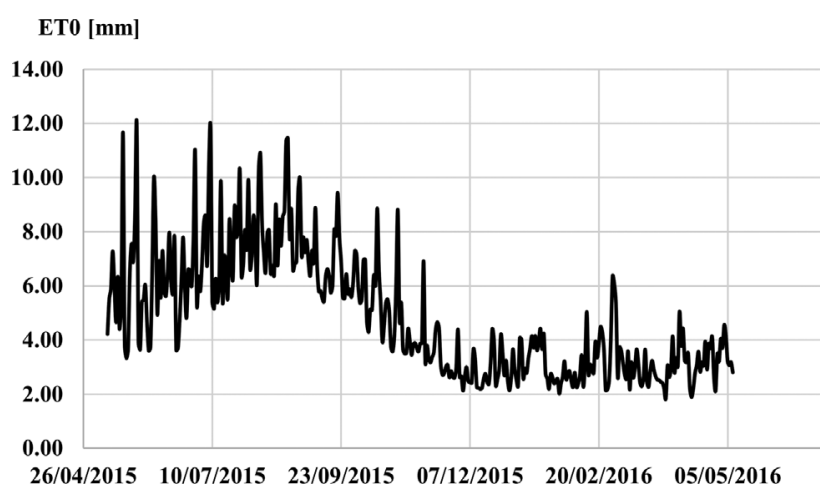

Figure 3 - Evapotranspiration at Mostaganem station. May 2015-May 2016 (ONM 2016).

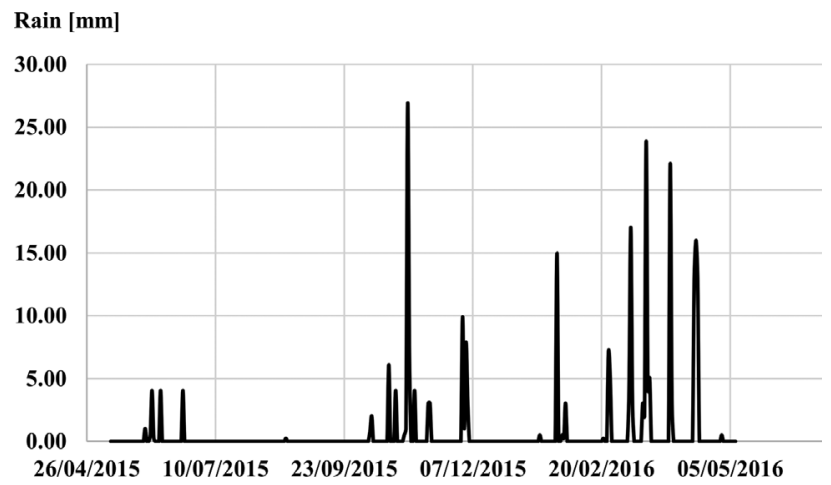

Figure 4 - Rainfall measured at Mostaganem station. May 2015-May 2016. (ONM 2016). 
According to Miossec (2004), the evaluation criteria are not universal, the principle is to compare the simulated and the observed flows. In this study, we used the following criteria:

\subsubsection{The mean square error RMSE}

$$
R M S E=\frac{1}{n} \sqrt{\left[\sum\left(\frac{\left(O V_{i}-S V_{i}\right)}{O V_{i}}\right)^{2}\right]}
$$

where $n$ is the number of observations; $O V_{i}$ is observed volume $i ; S V_{i}$ is simulated volume $i$.

\subsubsection{Index of agreement " $d$ "}

Willmott et al. (1985) developed the agreement index "d" to overcome the insensitivity of correlations between the observed and measured values. This index is given by:

$$
d=\frac{1-\sum_{i=1}^{n}\left(o b_{i}-s i_{i}\right)^{2}}{\sum_{i=1}^{n}\left(\left|s i_{i}-m O_{b}\right|+\left|O b_{i}-m O_{b}\right|\right)^{2}}
$$

This index varies from 0.0 to 1.0 . The unit indicates better agreement between the model and the observations, its interpretation is similar to the coefficient of determination $\mathrm{R}^{2}$.

\subsubsection{Ratio of observed volume to simulated volume}

According to Berthier (2005), the indices used to determine the performance criteria of simulation models are limited in practical use, so it is more appropriate to calculate the errors using the ratio of observed and calculated flow.

The following Fig. 5 illustrates the methodology applied in this study.

\section{Results and Discussion}

\subsection{Estimation of irrigation amounts}

The cumulative irrigation simulated by the model is $138,782 \mathrm{~m}^{3}$, whereas the irrigator used $135,688.5 \mathrm{~m}^{3}$, which is $2.3 \%$ less than the model (Fig. 6). Rainfall is $256.27 \mathrm{~mm}$, simulated cumulation (irrigation + precipitation) is $950.18 \mathrm{~mm}$ and real cumulation is $934.71 \mathrm{~mm}$. Our results show a slight overestimation of simulated values, based on the FAO dual crop coefficient method. It is considered the simplest approach to derive the coefficient $K_{c}$ from the remote sensing data (Calera Belmonte et al., 2005). This approach has been used and validated in other case studies (Bausch, 1995). The theoretical basis of the approach was established by Choudhury et al. (1994). Moran et al. (1997) concluded that the approach is one of the most promising for operational application. In addition, the use of NDVI promotes cross-calibration between different satellites, since the $N D V I$ values of the different sensors show the best correlations (Steven et al., 2003).

However, according to Toureiro et al. (2016), in the case of maize cultivated under Mediterranean climate, the same method overestimates irrigation requirements by about $20 \%$. The reasons for such a difference are easy to explain: the FAO methodology is intended for general applications, and may require calibration for different varieties and local crop conditions.

The results obtained by Er-Raki et al. (2009), also showed overestimation of the real evapotranspiration in the case of citrus grown in a semi-arid climate. These authors conclude that the drip irrigation technique allows better simulation of the $K_{c b}$ and $K_{e}$ coefficients by separating the soil evaporation fraction from the fraction transpired by the crop.

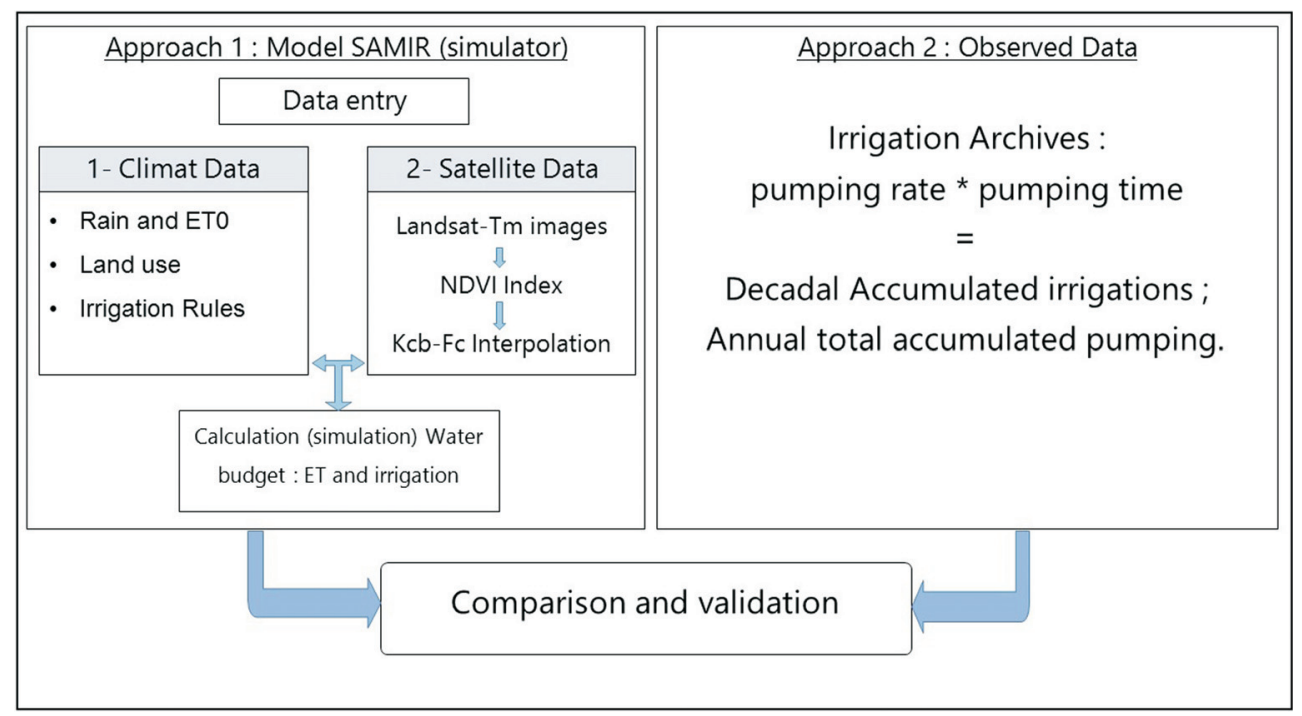

Figure 5 - Schematic diagram of the method. 


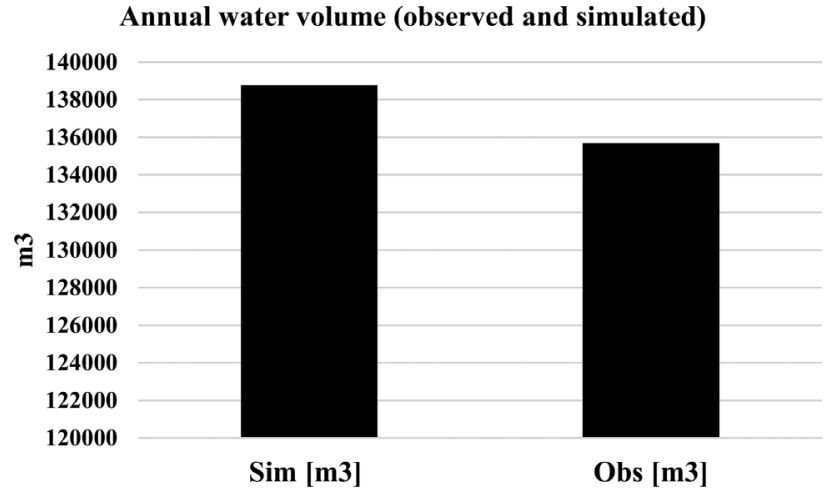

Figure 6 - Observed and simulated water volumes.

In the case of a partial vegetation cover, the proportion of bare soil can introduce and/or reinforce the effects on $K_{c}$ depending on the frequency of irrigation, the irrigation system used, as well as environmental and other factors. Researchs studies this behavior and to parameterize the effect of the contribution of soil evaporation to $K_{c}$ (Calera Belmonte et al., 2005).

Our study on a perennial monoculture (citrus), was more precise with an irrigation simulation close to $97.7 \%$ of the real irrigation. Even if the remote sensing methods are silent, and do not provide user information or the location of drill holes (Wada et al., 2010), their economic cost is 60 times lower than that of direct methods (Castaño et al., 2010). Thus, farmers use rational irrigation over a long period to limit interventions on the irrigation control equipment. Our study was based on real irrigation volumes with no adjustment, unlike the work of Castano et al. (2010) who adjusted theoretical water requirements using a correction coefficient $(\mathrm{Cc})$, and whose the results showed a performance of $95 \%$. This high rate of accuracy is due to the reliability of field-based crop classification (Castano et al., 2010). This also explains the slight difference between the real and the simulated irrigation volumes we obtained, mainly because the subject of our study is a monoculture whose phenological characteristics are known and identified.

The irrigation actually practiced during the study period corresponds to five different volumes according to the seasons (Fig. 7). Knowing that the pumping flow is $57.5 \mathrm{l} / \mathrm{s}$ $\left(207 \mathrm{~m}^{3} / \mathrm{h}\right)$, the volumes are as follows: $828 \mathrm{~m}^{3}, 931 \mathrm{~m}^{3}, 828$ $\mathrm{m}^{3}, 724 \mathrm{~m}^{3}$ and $828 \mathrm{~m}^{3}$.

A study on the water requirements of citrus fruit conducted in Egypt using the Penman-Monteith method, whose characteristics are comparable with our citrus, revealed an annual irrigation depth? of $994.3 \mathrm{~mm}$, and rainfall of $83.9 \mathrm{~mm}$, giving a total of $1078.2 \mathrm{~mm}$ with an estimated excess of $12.1 \%$ as drainage (Montoroi et al., 2014). This is slightly higher than our simulated results, estimated at $950.18 \mathrm{~mm}$ and the measured $934.71 \mathrm{~mm}$.

The same Fig. 7 shows the changes in irrigation simulated by the model controlled by a program that generates

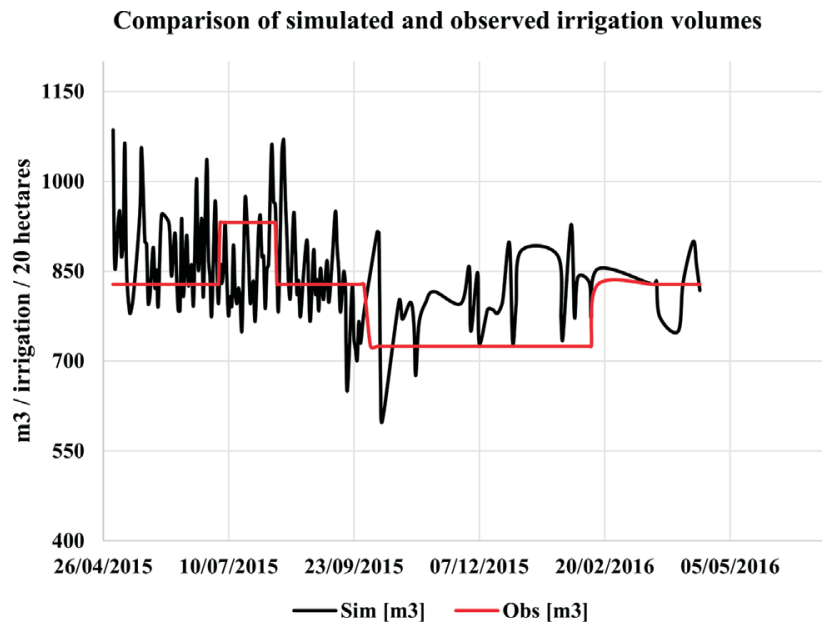

Figure 7 - Comparison of simulated and observed irrigation volumes.

water supplies and accounts for stress under ideal conditions (i.e. zero hydric stress). However, it remains close to the amounts provided by the irrigator, the ratio of observed volume to simulated volume ranged from $0.76 \mathrm{SI}$ to $1.27 \mathrm{SI}$ (Fig. 8). This difference can be explained by the fact that the model simulates the water deficit on a daily basis and compensates for the deficit by supplying water whenever the soil water reserve falls below a critical threshold.

The critical threshold is determined by the user and results in water fluctuations, whereas irrigation management follows a logic based on water needs for longer periods to limit human intervention on irrigation management equipment.

\subsection{Performance of the SAMIR model}

The correlation is done by comparing the simulated and estimated daily pumping. The model is based on filling the water reserve according to the crop water requirements, which causes variations in irrigation that can be sensitive on a daily scale but not at a large time scale. The calculation of the determination coefficient $R^{2}$ leads to mixed results due to the sensitivity of the fluctuations of the simulated pumped volumes compared to the measured pumped volumes. Therefore, we considered the RMSE indices, " $d$ " and

\section{Obs [m3] / Sim [m3]}

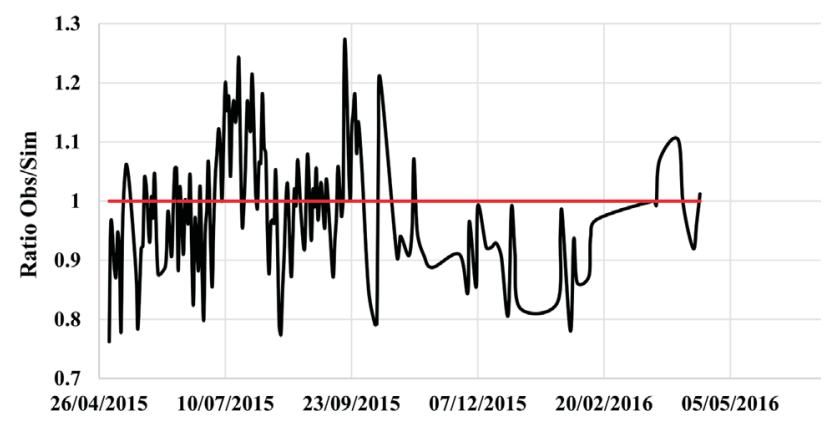

Figure 8 - Ratio of observed to simulated volume. 
Table 1 - Statistical performance index of the SAMIR model. In the table it should be Index of agreement.

\begin{tabular}{lc}
\hline$R M S E$ & «» Index of agrément \\
\hline 0.11 & 80.94 \\
\hline
\end{tabular}

the ratio (observed volume / simulated volume) indicated by Berthier (2005).

Table 1 shows the values of the RMSE and " $d$ " indices.

Figure 8 illustrates the different ratios (observed volumes: simulated volumes). Variations ranging from $0.76 \mathrm{SI}$ to $1.27 \mathrm{SI}$ were observed, with a difference of up to $31 \%$.

We ran 14 simulations with differences ranging from $20 \%$ to $30 \%, 42$ simulations with differences between $10 \%$ and $20 \%$ and 108 simulations with a difference of less than $10 \%$. This confirms the satisfactory performance of the SAMIR model in estimating irrigation volumes. However, irrigation at the daily scale is still complex to manage, because the daily climate demand is variable, reflecting oscillating crop water requirements, which correspond to the results obtained by Calera Belmonte et al. (2005), it is consequently advisable to use a weekly irrigation management schedule.

D’Urso (2001), used remote sensing images to derive $K_{c}$ in relation to $N D V I$ in the Italian pilot zone. It uses the definition of crop coefficient with both crop and reference evapotranspiration expressed in terms of the FAO-Penman-Monteith equation "e.g., Eq. (6) in Allen et al. (1998)". This leads to an expression of $K_{c}$ as an analytical function of LAI, albedo and roughness length, which are in turn estimated from remote sensing (D’Urso, 2001).

\section{Conclusion}

The availability of a digital record of water volumes distributed to irrigated plots allowed a factual comparison between simulated and observed pumped volumes. The difference of $2.3 \%$ confirms that the remote sensing method is appropriate for estimating pumped volumes of agricultural water.

The originality of this approach is the advantage of our model in estimating pumped groundwater, without the need for theoretical methods, only using real observations for better validation of the approach. The water requirements of citrus trees under Mediterranean conditions are in agreement with those used in the FAO method.

\section{Acknowledgments}

We thank the director and staff of the LMI-TREMA laboratory at Cadi Ayad University, especially Salah ErRaki and Said Khaba. The staff of the CESBIO of Paul Sabatier University Toulouse 3, particularly the coordinator of the PHC Maghreb project $\mathrm{N}^{\circ} 32592 \mathrm{VE}$, Valerie
Ledantec. Giles Boulet, Michel Lepage. Kuper Marcel and Khaldi Abdelkader are also gratefully acknowledged.

\section{References}

ABRISHAMCHI, A.; ALIZADEH, A.; TAJRISHY, M. Water resources management scenario analysis in the Karkheh river basin, Iran using the WEAP model. Hydrological Science and Technology, v. 23, p. 1-12, 2007.

ALLEN, R.G.; PEREIRA, L.S.; HOWELL, T.A.; JENSEN, M.E. Evapotranspiration information reporting: I factors governing measurement accuracy. Agricultural Water Management, v. 98, p. 899-920, 2011.

ALLEN, R.G.; PEREIRA, L.S.; RAES, D.; SMITH, M. Crop Evapotranspiration. Guidelines for computing crop water requirements. FAO Irrigation and Drainage Paper 56, Rome, Italy, 1998. 300 p.

BASTIAANSSEN, W.G.M. SEBAL-based sensible and latent heat fluxes in the irrigated Gediz Basin, Turkey. Journal Hydrologie, v. 229, p. 87-100, 2000.

BAUSCH, W.C. Remote sensing of crop coefficients for improving the Irrigation scheduling of corn. Agricultural Water Management, v. 27, n. 1, p. 55-68, 1995.

BENHADJ, I.; DUCHEMIN, B.; SIMONNEAUX, V.; MAISONGRANDE, P.; KHABBA, S.; CHEHBOUNI, A.G. Automatic unmixing of MODIS multi-temporal data for interannual monitoring of land use at regional scale (Tensift, Morocco). International Journal of Remote Sensing, v. 33, n. 5, p. 1325-1348, 2012.

BERTHIER, C.H. Quantification des incertitudes des débits calculés par un modèle empirique. Master II, Sciences de la terre spécialité hydrologie, hydrogéologie des sols, Université Paris-Sud 11, France, 2005. 50 p.

BEZERRA, B.G.; SILVA, B.B.; BEZERRA, J.R.C.; BRANDÃO, Z.N. Real actual evapotranspiration obtained through the relationship between the FAO-56 crop dual coefficient and NDVI. Revista Brasileira de Meteorologia, v. 25, n. 3, p. 404-414, 2010.

BLINDA, M.; THIVET, G. Faire face aux crises et pénuries d'eau en Méditerranée; Les Notes du Plan Bleu 4: environnement et développement durable en Méditerranée, Sophia Antipolis, France, 2006. 4 p.

CALERA-BELMONTE, A.; JOCHUM, A.; CUESTA-GARCIA, A.; MONTORO-RODRIGUEZ, A.; LOPEZ-FUSTER, P. Irrigation management from space: towards user friendly products. Irrigation and Drainage Systems, v. 19, p. 337 353, 2005.

CASTAÑO, S.; SANZ, D.; GÓMEZ-ALDAY, J.J. Methodology for quantifying groundwater abstractions for agriculture via remote sensing and GIS. Water Resources Management, v. 24, p. 795-814, 2010.

CHIBANE, B.; BENTCHAKAL, M.; MEDJERAB, A.; BENFARES, B. Etude de la variabilité et de la structure de pluie annuelle dans une région semi-aride: cas du bassin versant de la Mactaa (nord-ouest algérien). Larhyss Journal, n. 23, p. 213-229, 2015.

CHIROUZE, J.; BOULET, G.; JARLAN, L.; FIEUZAL, R.; RODRIGUEZ, J.C.; EZZAHAR, J.; ER-RAKI, S.; BIGEARD, G.; MERLIN, O.; GARATUZA-PAYAN, J. Intercomparison of four remote-sensing-based energy balance methods to retrieve surface evapotranspiration and water 
stress of irrigated fields in semi-arid climate. Hydrology and earth system sciences, v. 18, p. 1165-1188, 2014.

CHOUDHURY, B.J.; AHMED, N.U.; IDSO, S.B.; REGINATO, R.J.; DAUGHTRY, C.S.T. Relations between evaporation coefficients and vegetation indices studied by model simulations. Remote Sensing Environment, New York, v. 50, p. 1-17, 1994.

CLARKE, D.; SMITH, M.; EL-ASKARI, K. New software for crop water requirements and irrigation scheduling. International Commission Irrigation and Drainage, v. 47, p. 45-58, 1998.

D'URSO, G. Simulation and management of on-demand irrigation systems: A combined agrohydrological and remote sensing approach. PhD. Dissertation, Wageningen University; ISBN 90-5808-399-3, 174 p. 2001.

DANELICHEN, V.H.M.; BIUDES, M.S.; SOUZA, M.C.; MACHADO, N.G.; DA-SILVA, B.B.; NOGUEIRA, J.S. Estimation of soil heat flux in a neotropical Wetland region using remote sensing techniques. Revista Brasileira de Meteorologia, v. 29, n. 4, p. 469-482, 2014.

DELOGU, E.; BOULET, G.; OLIOSO, A.; COUDERT, B.; CHIROUZE, J.; CESCHIA, E.; LE-DANTEC, V.; MARLOIE, O.; CHEHBOUNI, G.; LAGOUARDE, J.P. Reconstruction of temporal variations of evapotranspiration using instantaneous estimates at the time of satellite overpass. Hydrology and earth system sciences, v. 16, p. 2995-3010, 2012.

DUCHEMIN, B.; HADRIA, R.; ER-RAKI, S.; BOULET, G.; MAISONGRANDE, P.; CHEHBOUNI, A.; ESCADAFAL, R.; EZZAHAR, J.; HOEDJES, J.C.B.; KHARROU, M.H.; KHABBA, S.; MOUGENOT, B.; OLIOSO, A.; RODRIGUEZ, J.C.; SIMONNEAUX, V. Monitoring wheat phenology and irrigation in Center of Morocco: on the use of relationship between evapotranspiration, crops coefficients, leaf area index and remotely sensed vegetation indices. Agricultural Water Management, v. 79, p. 1-27, 2006.

ER-RAKI, S.; CHEHBOUNI, A.; GUEMOURIA, N.; EZZAHAR, J.; KHABBA, S.; BOULET, G.; HANICH, L. Citrus orchard evapotranspiration: comparison between eddy covariance measurements and the FAO-56 approach estimates. Plant Biosystems, v. 143, n. 1, p. 201-208, 2009.

FAYSSE, N.; HARTANI, T.; FRIJA, A.; MARLET, S.; TAZEKRIT, I.; ZAÏRI, C.; CHALLOUF, A. Usage agricole des eaux souterraines et initiatives de gestion au Maghreb: Défis et opportunités pour un usage durable des aquifères. AFBD-BAFD, 24 p. 2011.

GLIZ, M.; REMINI, B.; ANTEUR, D.; MAKHLOUF, M. Vulnerability of soils in the watershed of Wadi El Hammam to water erosion (Algeria). Journal of Water and Land Development, n. 24, p. 3-10, 2015.

GONZALEZ-DUGO, M.P.; NEALE, C.M.; MATEOS, L.; KUSTAS, W.P.; PRUEGER, J.H.; ANDERSON, M.C.; LI, F. A comparison of operational remote sensing-based models For estimating crop evapotranspiration. Agricultural Water Management, v. 149, p. 1843-1853, 2009.

GONZÁLEZ-PIQUERAS, J. Evapotranspiration de la Cubierta Vegetal mediante la Determinación del Coeficiente de Cultivo por Teledetección. Extensión a Escala Regional: Aquífero 08.29 Mancha Oriental. Tese Doctoral apresentada na Universitat de Valencia, 2006.
HUETE, A.; JACKSON, R.; POST, D.; Spectral response of a plant canopy with different soil backgrounds. Remote Sensing, v. 17, p. 37-53, 1985.

KOFFI, Y.B. Etude du calage, de la validation et des performances des réseaux de neurones formels à partir des données hydro-climatiques du bassin versant du Bandama blanc en Côte d'Ivoire. These Doctorat, University of Cocody Abijan, 231 p. 2007.

KUPER, M.; FAYSSE, N.; HAMMANI, A.; HARTANI, T.; HAMAMOUCHE, M.F.; AMEUR, F. Liberation or Anarchy? The Janus Nature of Groundwater Use on North Africa's New Irrigation Frontiers. In: BARRETEAU, T.J.O.; HUNT, R.; RINAUDO, J.D.; ROSS, A. Integrated Groundwater Management, Editions Springer, Dordrecht, Pays-Bas, Sous presse, p. 583-615, 2016.

MARGAT, J. Exploitations et utilisations des eaux souterraines dans le monde. Paris: UNESCO and BRGM, 52 p. 2008.

MICHAEL, M.G.; BASTIAANSSEN, W.G. A new simple method to determine crop coefficients for water allocation planning from satellites: results from Kenya? Irrigation and Drainage Systems, v. 14, n. 3, p. 237-256, 2000.

MINACAPILLI, M.; IOVINO, M.; D’URSO, G. A distributed agro-hydrological model for irrigation water demand assessment. Agricultural Water Management, v. 95, p. 123-132, 2008.

MIOSSEC, M.P. Apport des multi-modèles pour la modélisation sur des bassins versants non jaugés. DEA Hydrologie, hydrogéologie, géostatistique et géochimie. Université Pierre et Marie Curie, Université de Paris-sud, Ecole Nationale du Génie Rural des eaux et des Forêts, CEMAGREF, Antony, France, 2004. 43 p.

MONTOROI, J-P.; NIZINSKI, G.; ZAGHLOUL, A.; ALI, R.; SABER, M. Optimisation de l'utilisation des ressources en eau: exemple de l'orangeraie d' El-Salam, nord Sinaï, Egypte (résumé de communication). In: Gaaloul N. (coord.) Ressources en eau et changement climatique en région méditerranéenne. Rome: FAO, 1 p. Eau-Climat' 2014: Regards Croisés Nord- Sud: Colloque International, 3. Hammamet (TUN), 2014/10/21-23, 2014.

NEALE, C.; JAYANTHI, H.; WRIGHT, J. Irrigation water management using high resolution airborne remote sensing. Irrigation and Drainage Systems, v. 19, n. 3-4, p. 321-336, 2005.

POUSSIN, J.; IMACHE, A.; BEJI, R.; LE-GRUSSE, P.; BENMIHOUB, A. Exploring regional irrigation water demand using typologies of farms production units: An example from Tunisia. Agricultural Water Management, v. 95, p. 973-983, 2008.

RAY, S.S.; DADHWAL, V.K. Estimation of crop evapotranspiration of irrigation command area using remote sensing and GIS. Agricultural Water Management, v. 49, p. 239249, 2001.

SAADI, S.; SIMONNEAUX, V.; BOULET, G.; RAIMBAULT, B.; MOUGENOT, B.; FANISE, P.; AYARI, H.; CHABAANE, Z.L. Monitoring Irrigation Consumption Using High Resolution NDVI Image Time Series: Calibration and Validation in the Kairouan Plain (Tunisia). Remote Sensing, v. 7, p. 13005-13028, 2015. 
SHAH, T. Taming the Anarchy: Groundwater Governance in South Asia. in: Resources for the Future, Washington, DC, 2009. $310 \mathrm{p}$.

SIEBERT, S.; BURKE, J.; FAURES, J.M.; FRENKEN, K.; HOOGEVEN, J.; DÖLL, P.; PORTMANN, F.T. Groundwater use for irrigation - a global inventory. Hydrology and earth system sciences, v. 14, p. 1863-1880, 2010.

SIMONNEAUX, V.; LEPAGE, M.; HELSON, D.; MÉTRAL, J.; THOMAS, S.; DUCHEMIN, B.; CHERKAOUI, M.; KHARROU, H.; BERJAMI, B.; CHEBHOUNI, A. Estimation spatialisée de l'évapotranspiration des cultures irriguées par télédétection: Application à la gestion de l'irrigation dans la plaine du haouz (Marrakech, Morocco). Secheresse, v. 20, p. 123-130, 2009.

SIMONNEAUX, V.; DUCHEMIN, B.; HELSON, D.; ER-RAKI, S.; OLIOSO, A.; CHEHBOUNI, A.G. The use of highresolution image time series for crop classification and evapotranspiration estimate over an irrigated area in central Morocco. International Journal of Remote Sensing, v. 29, p. 95-116, 2008.

STEVEN, M.; MALTHUS, T.; BARET, F.; XU, H.; CHOPPING, $M$. Intercalibration of vegetation indices from different sensor systems. Remote Sensing of Environment, v. 88, p. 412-422, 2003.
TOUREIRO, C.; SERRALHEIRO, R.; SHAHIDIAN, S.; SOU$\mathrm{SA}$, A. Irrigation management with remote sensing: Evaluating irrigation requirement for maize under Mediterranean climate condition. Agricultural Water Management, v. 184, p. 211-220, 2016.

WADA, Y.; BEEK, L.; BIERKENS, M.F. No sustainable groundwater sustaining irrigation: A global assessment. Water Resources Research, v. 48, n. 6, 2012.

WADA, Y.; VAN BEEK, L.P.; VAN KEMPEN, C.M.; RECKMAN, J.W.; VASAK, S.; BIERKENS, M.F. Global depletion of groundwater resources. Geophysical Research Letters, v. 37, n. 20, 2010.

WILLMOTT, C.J.; CKLESON, S.G.; DAVIS, R.E.; FEDDEMA, J.J.; KLINK, K.M.; LEGATES, D.R.; O’DONNELL, J.; ROWE, C.M. Statistiques pour l'évaluation et la comparaison des modèles. Journal of Geophysical Research, v. 90, n. C5, p. 8995-9005, 1985.

ZHANG, Y.; WEGEHENKEL, M. Integration of MODIS data into a simple model for the spatial distributed simulation of soil water content and evapotranspiration. Remote Sensing, v. 104, p. 393-408, 2006.

This is an Open Access article distributed under the terms of the Creative Commons Attribution Non-Commercial License which permits unrestricted non-commercial use, distribution, and reproduction in any medium provided the original work is properly cited. 